\title{
Bronchial hyperreactivity to histamine in aspirin sensitive asthmatics: relationship to aspirin threshold and effect of aspirin desensitisation
}

\author{
MAREK L KOWALSKI, IWONA GRZELEWSKA-RZYMOWSKA, MIROSLA W SZMIDT, \\ JERZY ROZNIECKI
}
From the Department of Pneumonology and Allergology, Institute of Internal Medicine, Academy of Medicine, Lódz, Poland

ABSTRACT Twenty seven aspirin sensitive asthmatic patients were studied to determine the relationship between non-specific bronchial responsiveness to inhaled histamine and the degree of sensitivity to aspirin (aspirin threshold dose). No correlation was found between provocative concentration of histamine $\left(\mathrm{PC}_{20} \mathrm{H}\right)$ and aspirin threshold dose. In 11 patients the influence of aspirin desensitisation on bronchial reactivity to inhaled histamine was examined. Mean $\mathrm{PC}_{20} \mathrm{H}$ measured the day after the patients were desensitised to $600 \mathrm{mg}$ of aspirin did not change significantly from the values before desensitisation. These observations suggest that sensitivity to aspirin and non-specific bronchial hyperreactivity in asthmatic patients are independent phenomena.

Aspirin sensitivity occurs in $4-10 \%$ of asthmatic patients and usually coincides with sensitivity to other non-steroidal anti-inflammatory drugs. ${ }^{2}$ Aspirin induced bronchospasm is not due to allergy but is thought to result from the interference of the drug with arachidonic acid metabolism in the lungs. ${ }^{34}$ Inhibition of cyclo-oxygenase by aspirin or other non-steroidal anti-inflammatory drugs may induce a decrease in synthesis of bronchodilating prostaglandins, leading to bronchoconstriction in sensitive asthmatics. Alternatively aspirin may activate the second pathway of arachidonic acid metabolism, resulting in overproduction of leukotrienes with strong bronchoconstrictor activity. ${ }^{5}$

The presence of bronchial hyperreactivity has been suggested as an essential factor for the development of bronchoconstriction after aspirin. ${ }^{2}$ Furthermore, bronchial responsiveness to several non-specific stimuli in aspirin sensitive asthmatic patients differs from that observed in patients not sensitive to aspirin..$^{6-8}$ We were interested in study-

\footnotetext{
Address for reprint requests: Dr Marek L Kowalski, Department of Pneumonology and Allergology, Institute of Internal Medicine, Medical Academy of Lódź, Kopcinskiego str 22, 90-153 Lódź, Poland.
}

Accepted 15 March 1985 ing the relationship between non-specific bronchial hyperreactivity and the degree of sensitivity to oral aspirin in aspirin sensitive asthmatic subjects. Since safe methods of desensitisation to aspirin have recently been developed ${ }^{9-11}$ we were able to investigate the influence of that procedure on bronchial responsiveness to histamine.

\section{Methods}

\section{PATIENTS}

The study included 27 patients with asthma and sensitivity to aspirin, 15 male and 12 female, ranging in age from 22 to 60 years (mean 37.4). All patients gave their informed consent before the study. Seventeen patients had an atopic history and positive responses to prick tests with at least one of eight common inhalant allergens; 23 had nasal polyps. Aspirin sensitivity was defined by a clear history and confirmed by provocative challenge with the drug. Aspirin threshold doses - that is, the smallest doses (in $\mathrm{mg}$ ) inducing at least a $20 \%$ fall in $\mathrm{FEV}_{1}$ - had been established by a double blind and placebo controlled oral challenge with increments of aspirin (usually 20,40,80,100,160,300, and $600 \mathrm{mg}$ ) on separate days two to four weeks before the study. ${ }^{2}$ At the time of the study symptoms of asthma were under control; the patients continued their usual 


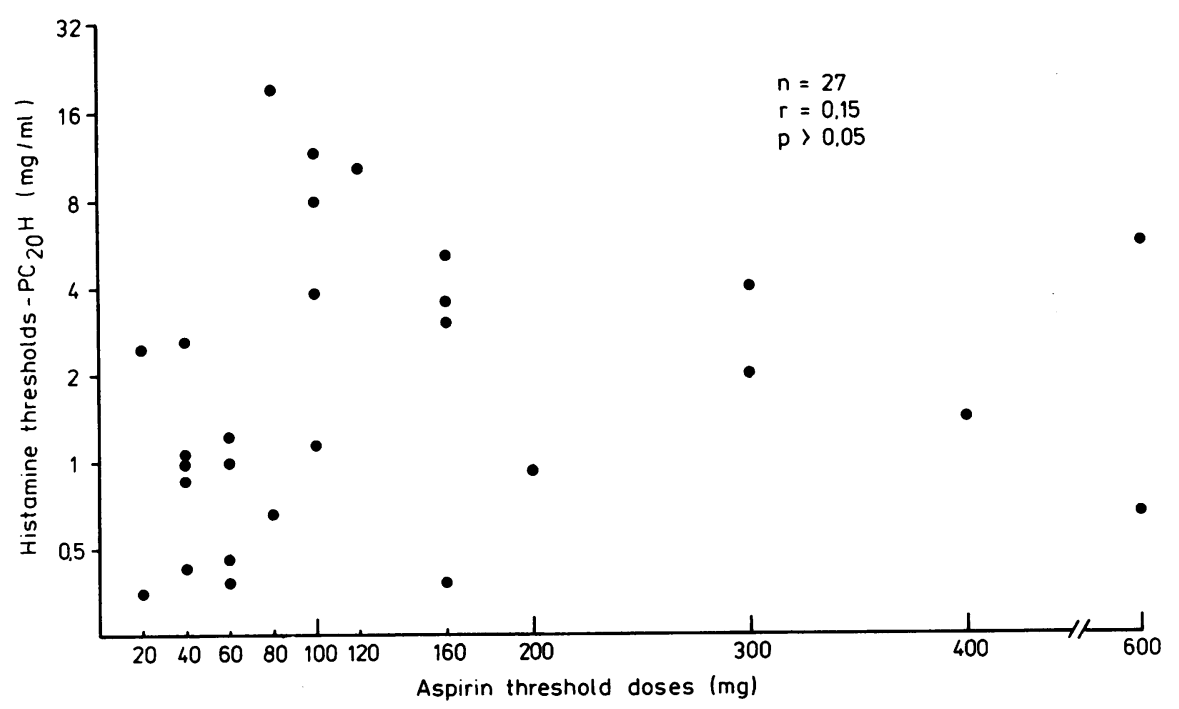

Fig 1 Relationship between sensitivity to aspirin (aspirin thresholds) in aspirin sensitive asthmatics and bronchial responsiveness to histamine $\left(\mathrm{PC}_{20} \mathrm{H}\right.$-provocation concentrations of histamine required to produce a fall in $F E V$, of $20 \%$ ).

medication but the drugs were stopped eight hours before aspirin or histamine challenge.

\section{STUDY DESIGN}

On the first day in 27 patients histamine inhalation tests were performed between 09.00 and 10.00 hours. During the next two to three days in all patients we began aspirin desensitisation with oral challenge with the aspirin threshold dose. Histamine challenges were repeated in 11 unselected patients on the morning after successful desensitisation to $600 \mathrm{mg}$ of aspirin. The study was conducted in a single blind fashion and aspirin challenges were placebo controlled.

\section{HISTAMINE INHALATION CHALLENGE}

The method of Cockcroft et al $^{12}$ was modified to fit standard techniques used in our pulmonary function laboratory. In brief, histamine hydrochloride solutions in isotonic saline were aerosolised in Wiesbadenner doppel nebulisers driven with an oxygen flow of 7 litres per minute (nebuliser output $0.12 \mathrm{ml}$ $\min ^{-1}$; mean particle size $\left.2.3 \mu \mathrm{m}\right)$. The $\mathrm{FEV}_{1}$ was measured in triplicate 30 seconds and 120 seconds after each inhalation. The protocol was for each subject to take 10 tidal breaths of control saline diluent alone followed by 10 breaths of increasing concentrations of histamine hydrochloride diluted in saline $(0.5,1.0,2.0,4.0,8.0,16.0,32.0 \mathrm{mg} / \mathrm{ml})$ at five minute intervals until there was at least a $20 \%$ fall in $\mathrm{FEV}_{1}$. The provocation concentration of histamine required to produce a fall in $\mathrm{FEV}_{1}$ of $20 \%\left(\mathrm{PC}_{20} \mathrm{H}\right)$ was calculated from the dose-response curve according to Cockcroft $e t a^{12}$ and served as the index of non-specific bronchial hyperreactivity. The definition of bronchial "hyperreactivity" used in our study corresponds to the "sensitivity" of Orehek et al..$^{13}$ Antiasthmatic medication was not administered for at least eight hours before the test and before the challenge the $\mathrm{FEV}_{1}$ was always greater than $70 \%$ of the patient's previous best value. The reproducibility of the histamine inhalation test was determined in eight asthmatic patients without aspirin sensitivity. The results of two histamine inhalation challenges repeated within one week were not significantly different $(\mathrm{p}>0.05$, geometric mean $\mathrm{PC}_{20} \mathrm{H} 1.97$ and $2.28 \mathrm{mg} / \mathrm{ml}$ respectively).

\section{ASPIRIN DESENSITISATION}

The method of inducing aspirin tolerance has been described in detail." We began with the oral administration of the previously established aspirin threshold dose and if an adverse reaction occurred then in the following days doubling aspirin doses were administered until $600 \mathrm{mg}$ was tolerated. When an aspirin challenge was followed by a decrease in $\mathrm{FEV}_{1}$ of less than $20 \%$ within four hours, on the next day the dose was increased by $20-30 \%$ and that provocative dose was used as an aspirin threshold dose for statistical analysis.

\section{STATISTICAL ANALYSIS}

Least squares linear regression was used to examine the relationship between $\mathrm{PC}_{20} \mathrm{H}$ and aspirin 


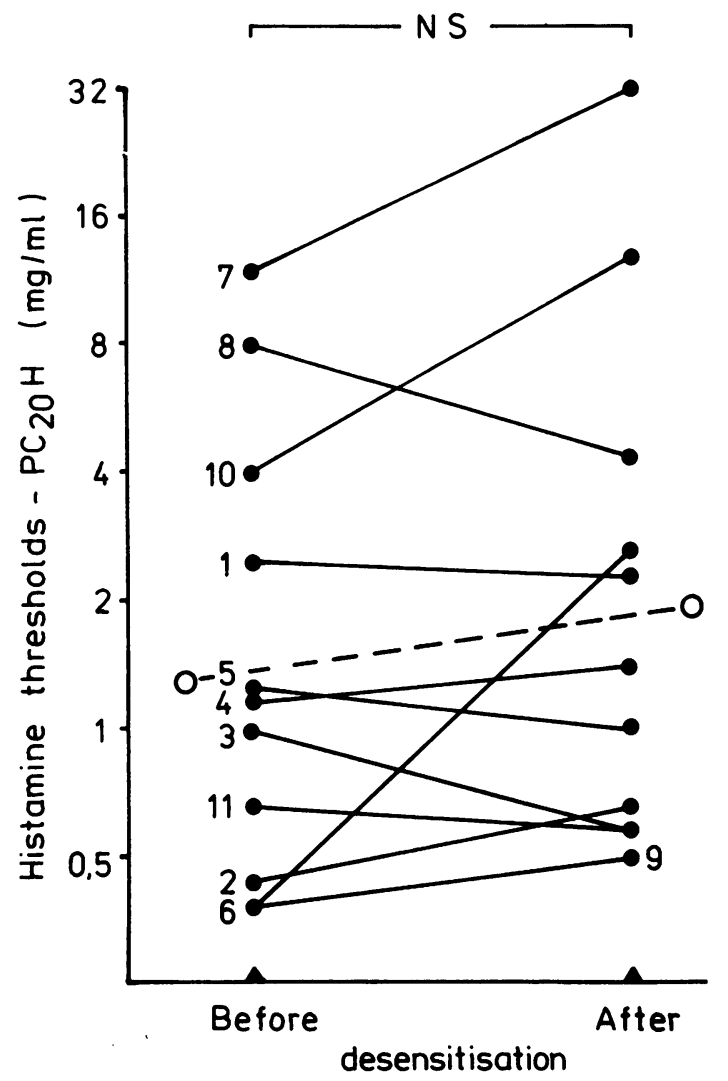

Fig 2 Infuence of aspirin desensitisation on bronchial responsiveness to histamine in 11 aspirin sensitive asthmatics. The open circles are geometric means of $P C_{20} H$ (see legend to fig 1). NS-difference not significant.

threshold dose. Changes in $\mathrm{PC}_{20} \mathrm{H}$ were analysed by a paired test with logarithmic transformations of the data.

\section{Results}

Patients showed large individual differences in bronchial responsiveness to histamine and $\mathrm{PC}_{20} \mathrm{H}$ ranging from $0.3 \mathrm{mg} / \mathrm{ml}$ to $20.0 \mathrm{mg} / \mathrm{ml}$. The aspirin threshold doses ranged from 20 to $600 \mathrm{mg}$. There was no significant correlation between $\mathrm{PC}_{20} \mathrm{H}$ and aspirin threshold dose $(r=0.15 ; \mathrm{p}>0.005$; fig 1$)$.

In 11 patients who were subsequently rechallenged with histamine aspirin desensitisation lasted from two to eight days and the cumulative doses of aspirin ingested during the procedure ranged from 1900 to $5220 \mathrm{mg}$ (table). In these patients we could compare $\mathrm{PC}_{20} \mathrm{H}$ measured on the two occasions. The day after tolerance to $600 \mathrm{mg}$ aspirin had been achieved three patients showed at least a twofold increase in $\mathrm{PC}_{20} \mathrm{H}$. One patient showed a halving of $\mathrm{PC}_{20} \mathrm{H}$ and in the remaining seven patients no significant changes in bronchial reactivity were noticed (fig 2). The geometric mean $\mathrm{PC}_{20} \mathrm{H}$ before desensitisation $(1.38 \mathrm{mg} / \mathrm{ml})$ and after desensitisation $(1.95 \mathrm{mg} / \mathrm{ml})$ did not differ significantly $(\mathrm{p}>$ $0.05)$. Baseline $\mathrm{FEV}_{1}$ values did not differ significantly between the first and second test (table).

\section{Discussion}

It has been well established that the response of the airways to both immunological and nonimmunological stimuli is influenced by the level of non-specific bronchial hyperreactivity as measured, for example, by histamine challenge..$^{14-16}$ Current evidence suggests also a correlation between the severity of asthma and the degree of non-specific bronchial responsiveness. ${ }^{17-19}$ Among aspirin sensitive asthmatic patients the amount of aspirin required to induce an asthmatic attack varies considerably. ${ }^{3}$ The patients show also appreciable intraindividual variability in susceptibility to aspirin; the degree of aspirin sensitivity, as measured by

Clinical details, aspirin threshold dose, and cumulative desensitising dose of aspirin in 11 patients undergoing aspirin desensitisation

\begin{tabular}{|c|c|c|c|c|c|c|c|c|}
\hline \multirow{2}{*}{$\begin{array}{l}\text { Patient } \\
\text { No }\end{array}$} & \multirow{2}{*}{$\begin{array}{l}\text { Age } \\
\text { (years) }\end{array}$} & \multirow[t]{2}{*}{ Sex } & \multirow[t]{2}{*}{ Atopy } & \multirow{2}{*}{$\begin{array}{l}\text { Aspirin } \\
\text { threshold } \\
\text { dose (mg) }\end{array}$} & \multirow{2}{*}{$\begin{array}{l}\text { Cumulative aspirin } \\
\text { dose during } \\
\text { desensitisation (mg) }\end{array}$} & \multirow{2}{*}{$\begin{array}{l}\text { Time interval between } \\
\text { the histamine } \\
\text { challenges (days) }\end{array}$} & \multicolumn{2}{|c|}{ Baseline FEV $(l)$} \\
\hline & & & & & & & 1st test & 2nd test \\
\hline $\begin{array}{r}1 \\
2 \\
3 \\
4 \\
5 \\
6 \\
7 \\
8 \\
9 \\
10 \\
11\end{array}$ & $\begin{array}{l}44 \\
28 \\
62 \\
22 \\
28 \\
37 \\
58 \\
43 \\
58 \\
45 \\
29\end{array}$ & $\begin{array}{l}\mathbf{M} \\
\mathbf{M} \\
\mathbf{F} \\
\mathbf{F} \\
\mathbf{M} \\
\mathbf{F} \\
\mathbf{M} \\
\mathbf{F} \\
\mathbf{M} \\
\mathbf{F} \\
\mathbf{F}\end{array}$ & $\begin{array}{l}- \\
\overline{+} \\
+ \\
+ \\
+ \\
- \\
+ \\
+ \\
+ \\
+\end{array}$ & $\begin{array}{r}20 \\
40 \\
40 \\
40 \\
60 \\
60 \\
100 \\
100 \\
200 \\
300 \\
600\end{array}$ & $\begin{array}{l}2080 \\
5220 \\
3840 \\
3980 \\
2480 \\
5040 \\
2400 \\
2200 \\
1900 \\
2100 \\
3600\end{array}$ & $\begin{array}{l}11 \\
9 \\
9 \\
8 \\
5 \\
8 \\
6 \\
7 \\
7 \\
4 \\
5 \\
\text { Mean (SD) }\end{array}$ & $\begin{array}{l}2.7 \\
2.4 \\
1.8 \\
4.7 \\
4.0 \\
2.0 \\
3.9 \\
3.7 \\
2.9 \\
3.0 \\
2.7 \\
3.07(0.87)\end{array}$ & $\begin{array}{l}3.3 \\
2.7 \\
1.8 \\
3.5 \\
4.1 \\
3.3 \\
4.0 \\
3.8 \\
3.4 \\
2.8 \\
2.9 \\
3.16(0.94)\end{array}$ \\
\hline
\end{tabular}


aspirin threshold dose, seems to reflect the severity of the underlying disease process at a given moment. ${ }^{20} \mathrm{We}$ might expect, then, that the level of bronchial hyperreactivity measured by inhaled histamine $\left(\mathrm{PC}_{20} \mathrm{H}\right)$ should predict the dose of aspirin that will trigger bronchoconstriction in aspirin challenge. In the present study, however, we could not find any correlation between the degree of sensitivity to aspirin, as reflected by aspirin threshold dose, and bronchial responsiveness to histamine. Our results suggest that the degree of non-specific responsiveness is not an essential determinant of the bronchoconstrictor response to aspirin in aspirin sensitive asthmatics. Consistent with this idea is the observation that the individual variability in susceptibility to aspirin (that is, change in aspirin threshold doses or even loss of sensitivity) concerns not only bronchoconstrictive responses but also the extrabronchial symptoms of adverse reactions to aspirin in asthmatic patients. ${ }^{29}$ These changes in the extrabronchial manifestations of aspirin sensitivity are apparently not related to the level of non-specific bronchial hyperreactivity. This finding points to the conclusion that individual sensitivity to aspirin is determined by factors other than bronchial hyperreactivity but common to bronchial and extrabronchial manifestations of aspirin induced adverse reactions. According to Szczeklik et al, ${ }^{34}$ the level of susceptibility of tissue cyclo-oxygenase to the inhibitory action of non-steroidal anti-inflammatory drugs may be the factor determining sensitivity to aspirin. Our results cannot, however, be interpreted unequivocally in terms of mechanisms of bronchial hyperreactivity since aspirin was given orally and individual variation in absorbtion and metabolism of the drug was not taken into account. On the other hand, an individual aspirin threshold dose should be considered to depend on several factors, such as aspirin absorption and metabolism and even target molecule (cyclo-oxygenase?) susceptibility. Aspirin threshold dose seems therefore to be a good clinical measure of aspirin sensitivity in a given patient.

It has been suggested that the bronchi of aspirin sensitive patients are dependent more on the bronchodilating activity of prostaglandin $\mathrm{E}_{2}\left(\mathrm{PGE}_{2}\right)$ than the bronchi of non-sensitive asthmatics. ${ }^{3}$ The presumption has further been supported by observations of different patterns of bronchial responsiveness to prostaglandins, histamine, and exercise in that group of patients. ${ }^{6-8}$ If the mechanism of bronchial hyperreactivity in aspirin sensitive asthmatic patients depended mainly on prostaglandins one would expect that profound disturbances of prostaglandin metabolism evoked by aspirin desensitisation $^{21}$ would significantly influence non-specific responsiveness of the bronchi. This apparently did not occur in our patients: neither the mean basal bronchial muscle tone, reflected in the $\mathrm{FEV}_{1}$, nor the mean $\mathrm{PC}_{20}$ histamine changed significantly after aspirin desensitisation. Similarly, aspirin desensitisation does not influence skin reactivity to intradermally injected histamine and codeine phosphate, although it may change skin responses to compound $48 / 80$, a mast cell degranulator. ${ }^{21} 22$

Recently we have noted that $600 \mathrm{mg}$ of aspirin administered daily for four weeks after desensitisation significantly increased histamine thresholds in most of 13 aspirin sensitive asthmatic patients and the changes in bronchial responsiveness paralleled the clinical improvement during aspirin treatment (unpublished observations). Taken together, these observations suggest that aspirin desensitisation itself does not affect bronchial hyperreactivity but prolonged aspirin treatment may influence the nonspecific responsiveness of the bronchial tree. Walters $^{23}$ showed that high single doses of non-steroidal anti-inflammatory drugs may modify bronchial responsiveness to histamine in asthmatic subjects sensitive to aspirin. In our study the cumulative doses of aspirin were administered during several days and perhaps it would be more relevant to test the influence of high single doses of aspirin or indomethacin on bronchial responsiveness to histamine in aspirin sensitive patients in the aspirin refractory state.

The mechanism of aspirin desensitisation remains obscure. As we have suggested previously, the aspirin induced refractory state in the bronchi might be related to persistent cyclo-oxygenase inhibition by aspirin during desensitisation and during that time the functional balance in the bronchi might be based on prostaglandin independent regulatory mechanisms that are not susceptible to the intervention of non-steroidal anti-inflammatory drugs." Present data seem to support this suggestion. From this study we may conclude also that the preservation of the airway responsiveness to histamine after desensitisation indicates that the tolerance to aspirin is neither the result of non-specific depression of bronchial smooth muscle nor the effect of local tachyphylaxis to endogenous histamine.

\section{References}

1 Samter $M$, Beers $R$. Intolerance to aspirin: clinical studies and consideration of its pathogenesis. Ann Intern Med 1968;68:975-83.

2 Grzelewska-Rzymowska I, Rożniecki J, Szmidt M, Kowalski ML. Asthma with aspirin intolerance. Clinical entity or coincidence of nonspecific bronchial hyperreactivity and aspirin intolerance? Allergol Immunopathol 1981;9:533-8.

3 Szczeklik A, Gryglewski RJ, Czerniawska-Mysik G. 
Clinical patterns of hypersensitivity to nonsteroidal anti-inflammatory drugs and their pathogenesis. $J$ Allergy Clin Immunol 1977;60:276-84.

4 Szczeklik A, Gryglewski RJ. Asthma and antiinflammatory drugs. Mechanisms and clinical patterns. Drugs 1983;25:533-43.

5 Samuelsson B. Leukotrienes: mediators of immediate hypersensitivity reactions and inflammation. Science 1983;220: 568-75.

6 Pasargiklian M, Bianco S, Allerga L, et al. Aspects of bronchial reactivity to prostaglandins and aspirin in asthmatic patients. Respiration 1977;34:79-91.

7 Szczeklik A, Niżankowska E, Nizankowski R. Bronchial reactivity to prostaglandin $F_{2}$ alfa, $E_{2}$ and histamine in different types of asthma. Respiration 1977;34:323-31.

8 Grabski W, Rożniecki J, Kowalski ML, GrzelewskaRzymowska I. Exercise-induced bronchospasm in pollen asthmatics and aspirin-sensitive asthmatics. Allergol Immunopathol 1980;8:332 (abstract).

9 Stevenson DD, Simon RA, Mathison DA. Aspirinsensitive asthma: tolerance to aspirin after positive oral aspirin challenges. $J$ Allergy Clin Immunol 1980;66:82-8.

10 Pleskow WW, Stevenson DD, Mathison DA, Simon RA, Schatz M, Zeiger RS. Aspirin desensitisation in aspirin-sensitive asthmatic patients: clinical manifestations and characterisation of the refractory period. $J$ Allergy Clin Immunol 1982;69:11-9.

11 Kowalski ML, Grzelewska-Rzymowska I, Rożniecki J, Szmidt M. Aspirin tolerance induced in aspirinsensitive asthmatics. Allergy 1984;39:171-8.

12 Cockcroft DW, Killian DN, Mellon JJA, Hargreave FE. Bronchial reactivity to inhaled histamine: a method and clinical survey. Clin Allergy 1977;7:23543.

13 Orehek J, Gayrard P, Smith P, Grimaud AP, Charpin $J$. Airway response to carbachol in normal and asthmatic subjects. Distinction between bronchial sensitivity and reactivity. Am Rev Respir Dis 1977;115:937-43.
14 Cockcroft DW, Ruffin RE, Frith PA, et al. Determinants of allergen-induced asthma: dose of allergen, circulating IgE antibody concentration, and bronchial responsiveness to inhaled histamine. Am Rev Respir Dis 1979;120: 1053-8.

15 Neijens HJ, Degenhart HJ, Raatgeep HC, Kerrebijn $\mathrm{KF}$. Study on the significance of bronchial hyperreactivity in the bronchus obstruction after inhalation of cat dander allergen. J Allergy Clin Immunol 1979;65:507-15.

16 Simonsson BG. Airway hyperreactivity. Definition and short review. Eur J Respir Dis 1983;64, suppl 131:11-25.

17 Boushey HA, Holtzman MJ, Sheller JR, Nadel JA. Bronchial hyperreactivity. Am Rev Respir Dis 1980;121:389-413.

18 Davies RJ, Morgan DJR, Blainey AD. Bronchial reactivity: its assessment and clinical value. In: Morley J, ed. Bronchial hyperreactivity. London: Academic Press, 1982:187-205.

19 Lam S, Tan F, Chan H, Yeung M. Relationship between types of asthmatic reaction, nonspecific bronchial reactivity and specific IgE antibodies in patients with red cedar asthma. J Allergy Clin Immunol 1983; 72:134-9.

20 Pleskow WW, Stevenson DD, Mathison DA, Simon RA, Schatz M, Zeiger RS. Aspirin-sensitive rhinosinusitis asthma: spectrum of adverse reactions to aspirin. J Allergy Clin Immunol 1983;71:574-9.

21 Asad SI, Kemeny DM, Youlten LJF, Frankland AW, Lessof MH. Effect of aspirin in "aspirin sensitive" patients. $\mathrm{Br}$ Med J 1984;288:745-8.

22 Kowalski ML, Szmidt M, Grzelewska-Rzymowska I, Rożniecki J. The effect of aspirin (ASA) during aspirin "desensitisation" on compound 48/80 and histamine induced skin responses in ASA-sensitive asthmatics. Allergy (in press).

23 Walters EH. Prostaglandins and the control of airways responses to histamine in normal and asthmatic subjects. Thorax 1983;38:188-94. 